\title{
Sea Level Rise in Indonesia: The Drivers and the Combined Impacts from Land Subsidence
}

\author{
Karlina Triana ${ }^{1, *}$ and A'an Johan Wahyudi ${ }^{1}$ \\ ${ }^{1}$ Research Center for Oceanography, Indonesian Institute of Sciences (LIPI), Pasir Putih Raya 1, Ancol Timur, Jakarta 14430, Indonesia \\ *Corresponding author: karlina.triana@gmail.com
}

\author{
KEYWORDS \\ Drivers \\ Land subsidence \\ Sea level rise \\ Spatial variations \\ SUBMITTED 1 July 2020 \\ REVISED 15 September 2020 \\ ACCEPTED 5 October 2020
}

\begin{abstract}
Sea level changes play an important role as an indicator of climate change. However, without climate change, the sea level itself shows strong regional patterns, both in space and time, that could deviate significantly from global averages. The spatial variability of sea level changes in Indonesia can be divided based on its drivers, i.e., climatic and seasonal weather-driven and non-climatic and geological-driven. Seasonally, the sea level in Indonesia is generally high in northwest monsoon and low in southeast monsoon. Nevertheless, there is a possibility of extreme natural phenomenon influences that generate anomalies and a thermosteric process that also affects the sea level. On the non-climatic and geological theory, the uniqueness of the tectonic setting in Indonesia will create spatial variations in regional sea levels, as both static and dynamic changes in a long period of time. Land subsidence is also often regarded as a significant contributor to the rise of relative sea level in coastal environments. Combined with the rise in sea level, land subsidence will escalate coastal flooding risks, contribute to shoreline retreat, and be further aggravated by anthropogenic forces such as groundwater extraction and land development. This scientific review will summarize the spatial variation of sea level rise in Indonesia, examines the underlying drivers that control it, and provides an overview of the combined sea level rise and land subsidence as a significant threat in Indonesia.
\end{abstract}

(c) The Author(s) 2020. This article is distributed under a Creative Commons Attribution-ShareAlike 4.0 International license.

\section{INTRODUCTION}

Climate change, indicated by the rising sea level, has the capability to affect various aspects of life. This threat is the result of two main variables, i.e., thermal expansion of the sea and the steric effect of icebergs melting around the poles (ICCSR 2010). For coastal communities and ecosystems, a sea level rise is jeopardy and closely related to a variety of coastal hazards such as coastal erosion, storm waves, and low land inundation (Nicholls et al. 2007).

A rising sea level does not occur in a uniform spatial pattern but shows a complex pattern, as indicated by the available observations (Douglas 2001; IPCC 2007). Regional and global averages of sea level rise are the aftermath of global warming. Changes in sea level show strong regional patterns (in space and time), which may deviate significantly from global averages (Stammer et al. 2013). Some regions experience local sea level rise faster and higher than the global average, whereas some local sea level rises that are far below or even negative from the global average may also occur in other regions.

An example of a non-uniform pattern can be found in the North Indian Ocean. Tide gauges placed along the coast combined with satellite altimetry showed that the sea level at several stations showed a rise of nearly 1 to $8 \mathrm{~mm}$ /year, whereas other stations experienced a decrease in sea level by as much as $3 \mathrm{~mm}$ /year (Chowdhury and Behera 2015). The data instantiate that the tide gauge measurement not only shows a positive trend but also shows a negative trend towards the sea level, the gap in the global estimation, and the local average.

Sea level variations are also influenced by human activities and natural phenomena on Earth, or geological processes. Groundwater extraction and land development as part of human activities, as well as natural phenomena that occur for long periods, can be the cause of vertical ground movements called land subsidence. Absolute sea level changes can occur due to these vertical ground movements (Stammer et al. 2013). Some South Asian and Southeast Asian countries are experiencing sea level rises that are related to land subsidence events. Thirteen stations of local tide gauges installed in the Gulf of Thailand revealed that the linear sea level rise trend in the last 25 years is around $5 \mathrm{~mm}$ /year (Sojisuporn et al. 2013). The higher annual mean sea level observed values are influenced by land subsidence that occurred around the local tide gauge stations. Meanwhile, in Bangladesh, along with the impact of land subsidence, it is estimated that the sea level will have risen by $10 \mathrm{~cm}$ by 2020 , and land below sea level will extend by $2 \%$ of the area $\left(2,500 \mathrm{~km}^{2}\right)$, and inundation will increase by $20 \%$ (Sarwar and Khan 2007).

In Indonesia, economic activity centers are mostly located in its coastal cities, making them very vulnerable to inundation. Sea level rises and land subsidence pose many risks to communities, ecosystems, and the economy. However, people are less certain about the magnitude and the geographic distribution that may vary with location. It is important for each coastal community (including the local 
government, public, institutions, and stakeholders) to understand and develop their strategy to overcome sea level rises according to its spatial variations, as well as the land subsidence factor, in the region. We need to compile and study the historical data and related theoretical foundations to further figure out the pattern. Therefore, the purpose of this review is to summarize the spatial variation of sea level rises in Indonesia, along with examining the underlying control drivers, and provides an overview of the combined sea level rise and land subsidence as a threat in Indonesia.

\section{THE DRIVERS OF SEA LEVEL RISE}

The sea level represents the average height of oceanic sea levels measured either from the center of the Earth's mass (absolute sea level) or relative to the crust or the seafloor (relative sea level) as an alternative (Stammer et al. 2013). According to Chambers et al. (2017), to understand the changes in the sea level there need to be an understanding of the drivers of these changes and how these drivers change over time. There have been some studies conducted about the spatial variation that causes differences in sea level rise in some regions. Theoretically, sea level changes on a global scale are associated with changes in total mass (freshwater content) and/or volume (heat content) of the oceans and are also associated with geometric deformation of the seafloor (Stammer et al. 2013). Contrarily, sea levels on a regional scale are influenced by atmospheric changes and ocean circulation (called dynamic changes) and by Earth processes such as ocean basin deformation, gravity variations, and ground motion effects (known as static changes).

A sea level rise is also often considered as being driven by temperature rises related to climate change (Cazenave and Cozannet 2014; Kopp et al. 2016; Nerem et al. 2018). We also agreed that sea level changes were originally related to seasonal weather. However, in recent years, seasonal weather is more complicated following climate change. The increases in greenhouse gas concentrations not only lead to the rising global mean and sea surface temperature but also cause an increase in sea levels by the thermosteric process that occurs in the ocean (ICCSR 2010). The IPCC AR4 analysis allocates $70 \%$ of the sea level rise to thermosteric processes and $30 \%$ to the melting of glacial ice (IPCC 2007). The thermosteric component of the global sea level increased by $0.54 \mathrm{~mm} /$ year for the $0-700 \mathrm{~m}$ layers and $0.41 \mathrm{~mm}$ /year for the 0-2000 m layers of the world ocean in 1955-2010 (Levitus et al. 2012). Therefore, we suggest that we need to see holistically that a sea level rise in Indonesia may also be climatically driven even though the process may be indirect.

Kopp et al. (2015) refer to the non-climatic geological background processes as one of the causes of changes in regional sea levels that differ significantly with changes in the global sea level. Stammer et al. (2013) also mention the geological aspects of seafloor deformation and Earth processes for the parameters of the global and regional sea level changes, respectively. We assumed that the nonclimatic or the geological process must also be understood as sea level drivers in addition to climatic factors. In this review, we will divide the drivers of sea level rise according (1) climatic and seasonal-weather driven, and (2) nonclimatic and geological driven. The non-climatic and geological drivers will be focused on the geological time-scale tectonic activity, which results in ocean basin deformation, along with land subsidence as another geological phe- nomenon that occurs more rapidly. The idea of hot spots from volcanic activities suggested by Nikolov (2012) was also considered to affect the thermal dynamics of the ocean and creates sea level variations on a regional scale.

\section{SPATIAL VARIATION OF SEA LEVEL RISE IN INDONESIA}

\subsection{Overview}

With thousands of small islands and tremendous coastlines, Indonesia is expected to encounter severe impacts from a sea level rise. The major impact will be felt by people living in coastal environments, especially in large cities along the northern coast of Java, which is occupied by more than $40 \%$ of the total population of Indonesia (ICCSR 2010). These cities are expected to suffer from flooding and inundation. Sea level data in Indonesian waters varies with time from the 1990s to 2019, but generally has an increasing tendency. Therefore, continuous rate measurements and future projections are needed to find out how severe the sea level rise is in Indonesia.

Some satellite altimetry radars have been launched and show a remarkable ability in sea level topography measurement with high accuracy, i.e., GeoSat (1985-1989), ERS-1 (1991-1998), TOPEX/Poseidon (1992-2006), ERS-2 (19952011), GFO (1998-2008), Jason-1 (2001-2013), EnviSat (20022012), Jason-2 (2008-2016), and Jason 3 (2016-present) (Fu and Cazenave 2001; Mansawan et al. 2017). Meanwhile, tidal gauge-based sea level data now interpret vertical land motion measuring (Fenoglio-Marc et al. 2012). The use of satellite altimetry to predict the trends of sea level rises in Indonesia reveals that Indonesia's average rate is higher than the global average. NOAA (2020), through data from TOPEX/POSEIDON and Jason 1-3 altimetry satellites, estimates that Indonesia experienced a sea level rise up to $3.9 \pm 0.4 \mathrm{~mm} /$ year between 1992 and 2020 (Figure 1). However, this rate is not uniform in all regions of Indonesia. The highest sea level trend in Indonesia was detected in the Pacific Ocean in the north of Papua, which reached 10-12 $\mathrm{mm}$ /year, while the lowest trend was detected in the south of Java, west of Sumatra, south of Nusa Tenggara, and the Karimata Strait, which only ranged 2-4 mm/year (FenoglioMarc et al. 2012; Nababan et al. 2015; Sofian et al. 2011; Sofian 2013; Sofian and Nahib 2010).

Fenoglio-Marc et al. (2012) have determined the vertical land motion that occurs around the tide gauge location by calculating the difference in sea level time series

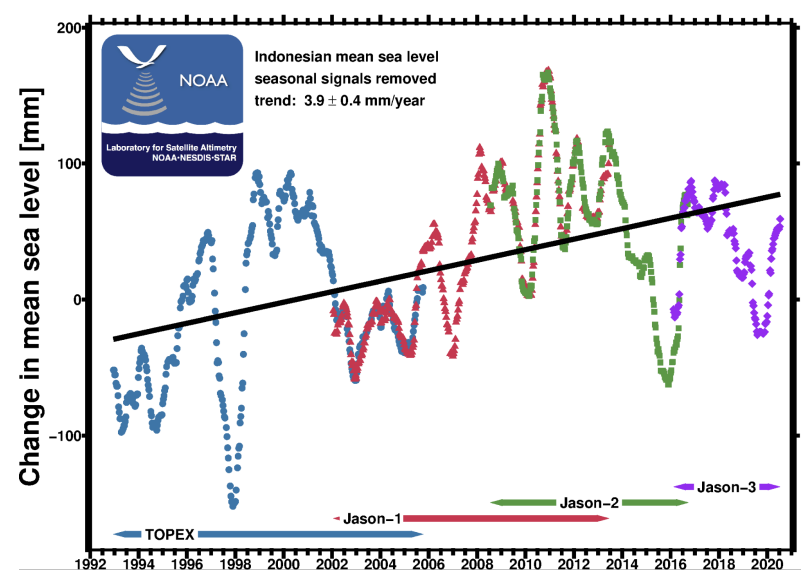

FIGURE 1. The trend of sea level rise in Indonesia in 1992-2020 is estimated to be $3.9 \pm 0.4 \mathrm{~mm} /$ year, based on NOAA (2020). 
of tidal gauges (1993-2009) and satellite altimetry, then computing the rates ((Table 1). The big difference between the sea level estimations measured by tidal gauges and satellite altimetry happens because of the seismic activities in Indonesia, which cause a high rate of vertical movement and displacement that eventually results in differences in sea level measurements. Low sea level trends of tide gauge and satellite altimetry time series were showed in Sibolga $(0.6 \pm 1.3 \mathrm{~mm} /$ year and $2.4 \pm 1.2 \mathrm{~mm} /$ year, respectively), meanwhile the vertical land motion rate determined from the difference between the two-time series shows a positive value. The highest vertical land motion trends were found in Jakarta $(-19.7 \pm 1.6 \mathrm{~mm} /$ year $)$ and followed by Benoa $(-11.9 \pm 1.4 \mathrm{~mm} /$ year). In the two locations, the tide gauge derived sea level trend is four and five times larger than the altimetric sea level trend. However, the land subsidence detected in Jakarta and Benoa is a known feature at these locations (Fenoglio-Marc et al. 2012).

Sofian and Nahib (2010) created a comparison of sea level projections using tide gauges, satellite altimetry, and IPCC-AR4 model data (Table 2). With a high level of confidence, the authors stated that the sea level rise in Indonesia will reach up to $80 \mathrm{~cm}$ by the year 2100 . However, the factor of thermosteric processes also needs to be considered for the more precise sea level rise projections. The models of thermosteric sea level rise made by Hieronymus (2019) show that the global equilibrium thermosteric rise of sea level is $0.7 \mathrm{~m}$ per ${ }^{\circ} \mathrm{C}$ of mean ocean warming. Sofian (2013) use the Oceanic General Circulation Model to also estimate the rate of sea level rise in Indonesia using the thermosteric factor as an additional parameter. Compared with the total sea level rise observed using an altimeter, the model shows that the thermosteric rise of sea level is higher, around $30 \%$. The model indicates that the thermosteric rise of sea level was about $20 \mathrm{~mm}$ from the total sea level rise of $58 \mathrm{~mm}$ in 1993. In the end, with the scenario of the sea temperature rising by more than $2^{\circ} \mathrm{C}$, the thermosteric rise in sea level itself will be $40-80 \mathrm{~cm}$ by 2100 , and the total rise in sea level in Indonesia will be up to $1-2 \mathrm{~m}$ by 2100 .

Most of Indonesia's neighboring countries' coastal areas have similar characteristics to it, with a low-lying topography, high population, and diversified economic activities (Paw and Thia-Eng 1991). However, apart from the geographical proximity and the similarity of the coastal characteristics, the rates of sea level rise of these countries are varying and even show a large deviation from the global average (Table 3). A higher rate than Indonesia's is found in Eastern Bangladesh, which reaches up to $7.8 \mathrm{~mm}$ /year (Sarwar and Khan 2007). The rates that are still within the range of Indonesia's rate are found in the Gulf of Thailand and Peninsular Malaysia (Luu et al. 2015; Sojisuporn et al. 2013). Meanwhile, some countries also have a lower rate than the global average and that of Indonesia; for example, Vietnam with a rate of $3.1 \mathrm{~mm}$ /year (Hanh and Furukawa 2007). The comparisons presented show that sea level rise is site-

TABLE 1. Vertical land motion measurement in $\mathrm{mm} /$ year based on satellite altimetry (AL) and tide gauge (TG) sea level time series (1993-2009), and the distance between Al and TG points (Fenoglio-Marc et al. 2012).

\begin{tabular}{lcccc}
\hline Station & TG & AL & AL-TG & Distance $(\mathrm{km})$ \\
\hline Benoa & $14.8 \pm 2.0$ & $3.2 \pm 1.1$ & $-11.9 \pm 1.4$ & 6.7 \\
Jakarta & $23.1 \pm 1.5$ & $3.8 \pm 1.0$ & $-19.7 \pm 1.6$ & 14.4 \\
Sibolga & $0.6 \pm 1.3$ & $2.4 \pm 1.2$ & $1.9 \pm 1.3$ & 25.2 \\
Surabaya & $8.8 \pm 1.2$ & $3.8 \pm 1.0$ & $-5.3 \pm 1.0$ & 8.9 \\
\hline
\end{tabular}

specific and the variables affecting the locations need to be understood.

\subsection{Climatic and seasonal-weather driven}

The sea level on the Pacific Ocean is generally higher than on the Indian Ocean (Sprintall 2009). This condition makes the region connected directly to the Pacific Ocean, such as northern Papua waters, more constantly higher than the region connected to the Indian Ocean. Apart from being influenced by the two oceans, the sea surface height of Indonesian waters is also varying significantly due to the seasons. Generally, the sea level in Indonesia is high in northwest monsoon and low in southeast monsoon (ICCSR 2010), and there is also a possibility of an extreme natural phenomenon effect that generates sea level anomalies.

Figure 2a shows that the propagation of the northwest monsoon wind causes waters from the Indian Ocean to enter the Java Sea through the Sunda Strait and move eastward. The eastward current pressure affected by the wind causes a difference in the sea level gradient, results in declining a sea level in the Java Sea, and increasing sea level in the Banda Sea and along the northern coast of Lombok (Sofian et al. 2008). The wind pattern changes with the changing seasons. Winds that blow from south-easterly in the southeast monsoon push the currents in the Karimata Strait to move north, while the currents in the Java Sea move west and then flow out through the Sunda Strait (Figure 2b; Sofian et al. 2008). However, the sea surface height in southern Indonesian waters tends to be more stead throughout the year and more influenced by the upwelling events (Purba et al. 2020).

The significant sea surface height and current in the northern Karimata Strait occurring during the northwest monsoon are influenced by the South China Sea. Sea surface height in the South China Sea is one of the highest due to the water transfer and tides from the north Pacific Ocean (Purba et al. 2020). The difference in sea level height of $40 \mathrm{~cm}$ between the Java Sea and Karimata Strait is also reportedly caused by the topographic effect of shrinking and shallowing of the southern Karimata Strait depth (ICCSR 2010). Unlike the flow patterns in the Java Sea and Karimata Strait, the pattern of surface currents in the Makassar Strait does not follow seasonal patterns and wind direction. In the Makassar Strait, surface currents tend to move south (Figures 2a and 2b).

Although the north wind is very intensive, the speed of surface currents in the Makassar Strait is weak during the northwest monsoon, which is caused by the obstruction of surface flow in the Makassar Strait to the south due to the strong surface currents in the Java Sea (Sofian et al. 2008). Besides that, due to the surface currents in the Makassar Strait, which are stronger in the southeast monsoon, the sea level decreases along the northern coast of Lombok Is-

TABLE 2. Projection of sea level rise in Indonesia using tide gauge, satellite altimetry, and model (Sofian and Nahib 2010).

\begin{tabular}{ccccl}
\hline \multirow{2}{*}{ Year } & \multicolumn{2}{c}{ Sea level rise projection $(\mathrm{cm})$} & \multirow{2}{*}{ Level of confidence } \\
\cline { 2 - 4 } & $\begin{array}{c}\text { Tide } \\
\text { gauge }\end{array}$ & $\begin{array}{c}\text { Satellite } \\
\text { altimetry }\end{array}$ & Model & \\
\hline 2030 & $24.0 \pm 16.0$ & $16.5 \pm 1.5$ & $22.5 \pm 1.5$ & Moderate \\
2050 & $40.0 \pm 20.0$ & $27.5 \pm 2.5$ & $37.5 \pm 2.5$ & Moderate \\
2080 & $64.0 \pm 32.0$ & $44.0 \pm 4.0$ & $60.0 \pm 4.0$ & High \\
2100 & $80.0 \pm 40.0$ & $60.0 \pm 5.0$ & $80.0 \pm 5.0$ & High \\
\hline
\end{tabular}


TABLE 3. Sea level rise rate (SLRR) in surrounding countries using tide gauge method.

\begin{tabular}{lcl}
\hline Country & SLRR $(\mathrm{mm} /$ year) & Reference \\
\hline Gulf of Thailand & 5.0 & (Sojisuporn et al. 2013) \\
Peninsular Malaysia & $4.4-4.6$ & (Luu et al. 2015) \\
Bangladesh & $4.0-7.8$ & (Sarwar and Khan 2007) \\
Vietnam & 3.1 & (Hanh and Furukawa 2007) \\
\hline
\end{tabular}

land, Flores Sea, and also the eastern and central Java Sea in August (Figure b). Meanwhile, the highest sea level in the north Papua waters can be found in southeast monsoon and comes from the Pacific Ocean (Purba et al. 2020).

Extreme natural phenomena, such as La Niña and El Niño, are also closely related to sea level variability in Indonesia and spatially very homogeneous on an annual and decade scale (Fenoglio-Marc et al. 2012). Sea level variability in Indonesian waters tends to decline during El Niño and is altered when La Niña occurs. The anomalies occur because warm water that is supposed to be in Indonesian waters moves eastward during El Niño and then reduces the volume of the ocean and sea level (Sofian et al. 2008). Meanwhile, the upwelling in the warm water of the ocean will move to Indonesia during La Niña and then increase the volume and the level of the sea.

The situation in which sea levels were extremely low in the west of Sumatra, south of Java, and south of Bali waters in 1994, 1997, and 2006 occurred due to El Niño with the minimum Southern Oscillation Index (SOI) coinciding with the positive Indian Ocean Dipole (IOD). On the other hand, in the La Niña years, it coincided with the maximum SOI and the negative IOD (1999, 2008, and 2011), the sea level anomaly values were found to be relatively higher (Nababan et al. 2015). The same pattern of sea level anomalies affected by El Niño and La Niña was also found in eastern Indonesia. In the El Niño period, the sea level will be depressed by $20 \mathrm{~cm}$ below normal and will be elevated by $10-$ $20 \mathrm{~cm}$ during La Niña (Sofian et al. 2011).

However, these anomalies were not found to be uniform in all regions of Indonesia. Opposite to the waters that are directly connected to the Indian Ocean and the Pacific Ocean, there is no significant effect on sea level anomalies in closed waters, such as the Banda Sea, Natuna Sea, and north of Java waters, from the extreme climate events of El Niño and La Niña (Nababan et al. 2015). Sea level anomalies are more influenced by seasonal fluctuation patterns, not by extreme climatic events. In the end, the increasing intensity of El Niño and La Niña can result in higher rates of shoreline change.

\subsection{Non-climatic and geological driven}

Although nowadays most of the discussions and analyses regarding sea level changes are related to climate signals, we cannot neglect that between the end of the last deglaciation and the twentieth century, the main drivers of the change in sea level rise at many locations were geological factors. Geological factors are also often regarded as climate drivers (in the form of tectonic activities), affecting topography changes, glaciation, denudation, biota evolution, hydrological cycle, and carbon sequestration (Gerhard et al. 2001). The uniqueness of the tectonic setting in Indonesia will create spatial variation in regional sea levels, both in static and dynamic changes of the ocean as described below.

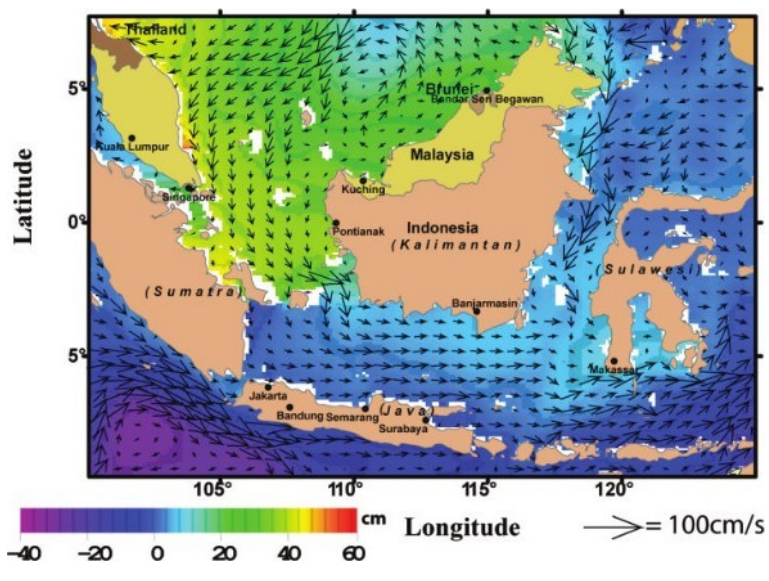

(a)

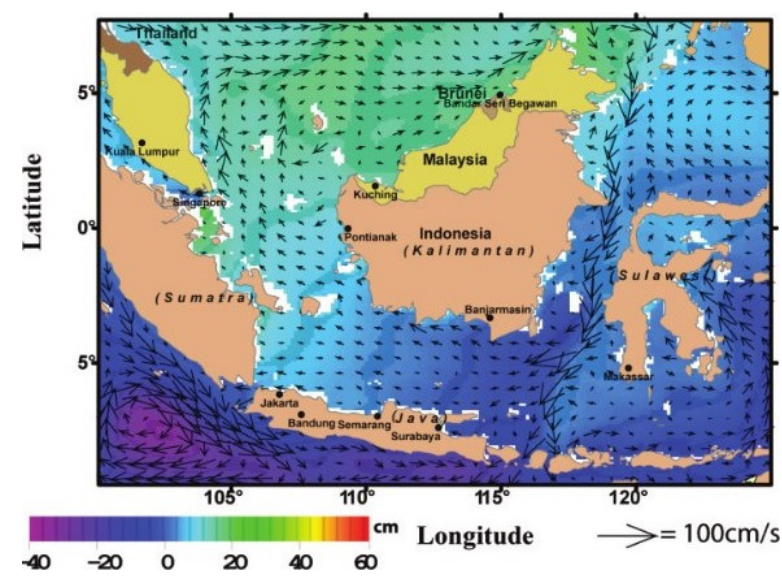

(b)

FIGURE 2. Average sea level and surface current pattern from 1993 to 1999 in (a) northwest monsoon and (b) southeast monsoon (ICCSR 2010).

The ocean basin deformation that has been occurring along with tectonic activities on Earth for millions of years also made significant contributions to the changes in regional sea levels without most humans knowing it. These changes were driven by mantle flow, linked to plate tectonics that move the continents. The opening and the closing of the oceanic basin, the rising and the falling of the mountains, etc., will create land deformation that affects regional sea levels. Therefore, mantle dynamic topography becomes important to be considered as the older sea level marker (Kopp et al. 2015). The volcanic arc in western Indonesia was formed by the subduction of the IndoAustralian oceanic plate beneath the Eurasian continental plate. Meanwhile, the tectonic activities in the eastern part of Indonesia are controlled by the Pacific and IndoAustralian oceanic plate movements. The differences in plate movements in western and eastern Indonesia will create spatial variations in the regional sea level changes.

Nikolov (2012) proposed a hypothesis of hot spots influences in the lithosphere on climatic variations. The tremendous heat source of a hot spot that comes from the earth's core (as volcanic activities) and affecting the thermal dynamics of the oceans became the base of this hypothesis. The majority of Indonesia's volcanoes are located on the Sunda Arc, a $\pm 3,000 \mathrm{~km}$-long chain of a volcanic arc that produced the islands of Sumatra and Java, the Sunda Strait, and the Lesser Sunda Islands. The heat derived from coremantle hot spots in the Sunda Arc is certainly higher and affects the thermal dynamics of the ocean.

Another geological process that is related to sea level changes is land subsidence. Generally, land subsidence is 
the sinking or lowering of the land/ground surface. The unconsolidated sediments on the ground surface compact under their weight, and the pressure leads to pore space reduction and shrinking in the overall sediments (Horton and Shennan 2009; Kolker et al. 2011). Land subsidence is often regarded as a significant contributor to observed sea level change on both historical and Pleistocene (last 2.6 Myr) timescales (Kopp et al. 2015). In Indonesia itself, the busiest cities are located on the North coast of Java and consist of alluvial plains lithology that is still in the consolidation stage. This condition leads the land to subside and strongly influences the extent area of tidal flooding in the future (Wibowo et al. 2015).

Although land subsidence is slow and can hardly be felt by humans, its effects accumulate over time and are further aggravated by anthropogenic forces such as groundwater extraction and land development (Sarah and Soebowo 2018). Anthropogenic land subsidence may be the major contributor to the rising of relative sea levels in coastal areas where the groundwater is heavily exploited (Ingebritsen and Galloway 2014). These anthropogenic forces accelerate the natural subsidence due to geological processes. The risk of flood and foundation problems caused by land subsidence could be increased as the result of deep well pumping activities. This increased risk is supported by the character of the flat, low-lying topography of coastal areas and the presence of a thick, soft, clay lithology at the ground surface (Phien-wej et al. 2006).

Accurate measurements and predictive tools are needed to enhance the knowledge of land subsidence because its rates and locations change over time. There are several reliable tools for land subsidence measurements (Eggleston and Pope 2013; Sarah and Soebowo 2018):

- Borehole extensometer; measuring the compaction and expansion of the aquifer system independently from vertical movements such as crustal and tectonic motions.

- Tidal station measurements; sea level measurements are averaged over time to remove the effect of waves, tides, and other short-term fluctuations to determine long term trends.

- InSAR analysis combined with the geodetic survey; InSAR has the advantage of measuring subsidence in a large area, whereas geodetic leveling and GPS surveying are performed at the locations.

\section{SIGNIFICANT THREAT OF COMBINED SEA LEVEL RISE AND LAND SUBSIDENCE}

Sea level trends influenced by the climate are reinforced by vertical land motion and their impacts on coastal areas should be seriously considered (Fenoglio-Marc et al. 2012). In terms of its impact on sea level changes, land subsidence has a shorter time span and more measurable magnitude compared with the influences of tectonic setting. According to Eggleston and Pope (2013), land subsidence can increase floods, alter wetland and coastal ecosystems, and damage infrastructures and historical sites. It occurs in a rapid human lifetime scale, not a geological timescale. Global sea level rises and land subsidence will increase coastal flooding risks and contribute to shorelines retreating (Eggleston and Pope 2013), and the magnitude and frequency of near-shore coastal flooding will increase in accordance with the rise of the relative sea level.

The increasing demand for groundwater resources in developed and populated cities appears to accelerate the rate of subsidence and leads to the worsening of other collateral hazards, i.e., tidal flooding (Abidin et al. 2010). Several areas along the coast of Jakarta, Semarang, and other coastal cities in Indonesia have already experienced this tidal flooding during high tide periods. Fatalities will be more severe if there is an increase in sea level and land subsidence. It is important for regional planners to project how fast land subsidence occurs in the present and future. Furthermore, the more measurable magnitude of land subsidence (compared with other non-climatic factors that influence sea level rise) can reduce or even prevent the impact of this combined phenomenon.

With InSAR time series spatial analysis, Chaussard et al. (2013) identified nine locations that experience subsidence at rates up to $22.5 \mathrm{~cm}$ /year. In Medan, Jakarta, Bandung, and Semarang, groundwater extraction for industrial use is responsible for rapid and patchy subsidence, with a rate of $4.8,7.2,7.2$, and $4.8 \mathrm{~cm} /$ year, respectively. The pattern of these subsidence events occurs on a large scale, caused by the combination of Holocene sediments' natural compaction and anthropogenic processes. Meanwhile, groundwater extraction for agricultural use is responsible for subsidence around Pekalongan and Blanakan, with a rate of 4.8 $\mathrm{cm} /$ year for both cities. The subsidence pattern was also rapid, patchy, and large, but mainly related to the harvesting schedule or seasonality of agricultural activities. Gas extraction also causes local subsidence, as observed in other areas. Although the subsidence events were not correlated with the land use pattern, gas extraction in the Arun gas field was expected to be responsible for subsidence events in Lhoksemawe $(4.2 \mathrm{~cm} /$ year), while gas extraction in the Wunut gas field was related to subsidence events in Sidoarjo (4.8 cm/year). In contrast, several cities developed in compressible sediments such as Pekanbaru, Depok, Bekasi, and Surabaya. Their rates were below $2 \mathrm{~cm} /$ year (below InSAR detection), potentially because of lower rates of groundwater extraction for industrial use.

Based on the rate of land subsidence, Chaussard et al. (2013) estimate the time until the coastal parts of the cities are below the relative sea level. The coastal parts of Lhokseumawe and Medan will be below the relative sea level in 60 years with the assumption that the average elevation is $5 \mathrm{~m}$ above the relative sea level and the subsidence rate is $8 \mathrm{~cm} /$ year. In Blanakan, Pekalongan, and Semarang, with a subsidence rate of $10 \mathrm{~cm} /$ year and an average elevation of 5 $\mathrm{m}$ above the relative sea level, the agricultural coastal areas in these cities will be below the relative sea level in 50 years. We also made scenarios of the time until the coastal part of Jakarta is below the relative sea level (Figure 3), but this time equipped with the comparison between the increase in relative sea level caused by the sea level rise itself (SLR) and those caused by the combination of sea level rise and land

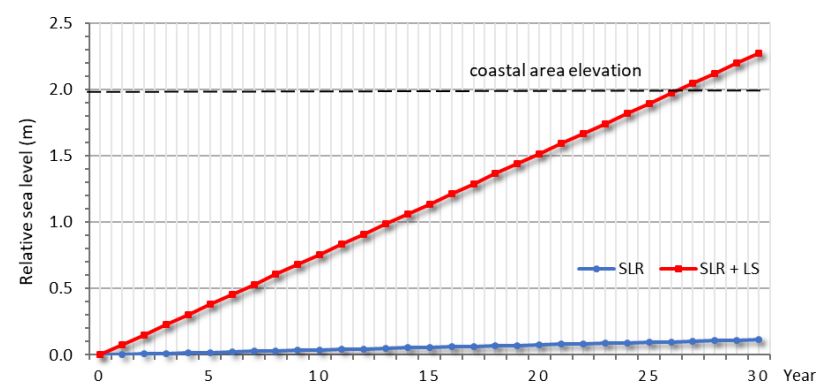

FIGURE 3. Increase in relative sea level in Jakarta with the scenarios of sea level rise only (SLR) and combination of sea level rise and land subsidence $(S L R+L S)$. 
subsidence (SLR + LS). The assumptions are that land subsidence continues at an average rate of $7.2 \mathrm{~cm} /$ year (Chaussard et al. 2013), sea level increase at a rate of $3.8 \mathrm{~mm} /$ year (Fenoglio-Marc et al. 2012), and the average elevation of the coastal area at $2 \mathrm{~m}$. In the SLR + LS scenario, the coastal part of Jakarta will be below the relative sea level in 27 years. Meanwhile, in the same year, the relative sea level will only rise to $10 \mathrm{~cm}$ with the SLR scenario. All of these estimates give an idea of how terrific the land subsidence impact is on the rise of sea level.

Using the combination of sea level rise and land subsidence variables in economic and risk estimation, Jakarta is projected to face a USD 521 million loss risk caused by flooding in 2030 (Widodo 2017). The Indonesian government has already joined and signed the Paris Agreement, an embodiment in the international community to minimize the GHG effect and reduce climate change. To protect the capital city from sinking, the Indonesian government also launched the NCICD project, which consists of two main actions: sea wall building and land reclamation. Each government of the cities that face land subsidence and sea level change should ensure that the City Spatial Planning is wellimplemented. Rules on groundwater extraction, which is recognized as the major cause of land subsidence, have to be obeyed comprehensively (Widodo 2017). The public and stakeholders alike should be more aware of the process and drivers of sea level rise and land subsidence, as well as the economic impacts they can receive. This purpose can be achieved by bridging scientific information into administrative policy and control, and persuading the active involvement of local stakeholders (Sarah and Soebowo 2018).

\section{CONCLUSIONS}

We divided the spatial variations of sea level rise in Indonesia based on its drivers, i.e., climatic and seasonal weatherdriven and non-climatic and geological-driven, to discuss the complex pattern of sea level trends. Based on the climatic side, the sea level in Indonesia is generally high in northwest monsoon and low in southeast monsoon, but there is a possibility of extreme natural phenomenon effects (such as La Niña and El Niño) that generate sea level anomalies. The thermosteric process also needs to be considered in sea level measurement. On the non-climatic side, the uniqueness of the tectonic setting in Indonesia will create spatial variations in regional sea levels over a long period of time. Deformation of the land and oceanic floor affect the sea level as the static change. Meanwhile, the heat derived from core-mantle hot spots affects the sea level as the dynamic change.

Land subsidence is also often regarded as a significant contributor to observed sea level changes and has a shorter period compared with the influences of tectonic setting. Global sea level rises and land subsidence will increase coastal flooding risks, contribute to shoreline retreats, with anthropogenic forces such as groundwater extraction and land development aggravating them further. With land subsidence measurements, the time when the elevation of a coastal city is below the relative sea level can be predicted, and the necessary actions to reduce the impacts of sea level rises and land subsidence in a coastal city can be arranged early on by a regional planner. Each government of the respective cities that face coastal land subsidence and sea level changes should ensure that their spatial planning is well-implemented. Stakeholders and the general public should also be made more aware of sea level rises and land subsidence, and the economic impacts that may follow.

\section{ACKNOWLEDGMENTS}

The authors would like to thank the reviewers and editor for their assistance in the improvement of this paper.

\section{AUTHORS' CONTRIBUTIONS}

Both authors contributed to the writing and conceptualizing of the work. KT wrote the original draft and AJW supervised the manuscript.

\section{COMPETING INTERESTS}

The authors declare none of the competing financial interests that could appear to influence the work reported in this paper.

\section{REFERENCES}

Abidin H, Andreas H, Gamal M, Gumilar I, Napitupulu M, Fukuda Y, Deguchi T, Maruyama Y, Riawan E. 2010. Land subsidence characteristics of the Jakarta basin (Indonesia) and its relation with groundwater extraction and sea level rise. In: Taniguchi M, Holman IP, editors. Groundwater response to changing climate. Leiden: CRC Press/Balkema. p. 113-130.

Cazenave A, Cozannet GL. 2014. Sea level rise and its coastal impacts. Earth's Future. 2(2):15-34. doi:10.1002/2013ef 000188.

Chambers DP, Cazenave A, Champollion N, Dieng H, Llovel W, Forsberg R, von Schuckmann K, Wada Y. 2017. Evaluation of the global mean sea level budget between 1993 and 2014. Surv Geophys. 38(1):309-327. doi:10.1007/s1 0712-016-9381-3.

Chaussard E, Amelung F, Abidin H, Hong SH. 2013. Sinking cities in Indonesia: ALOS PALSAR detects rapid subsidence due to groundwater and gas extraction. Remote Sens Environ. 128:150-161. doi:10.1016/j.rse.2012.10.015.

Chowdhury P, Behera MR. 2015. A study on regional sea level variation along the Indian coast. Procedia Eng. 116(1):1078-1084. doi:10.1016/j.proeng.2015.08.348.

Douglas BC. 2001. Sea level change in the era of the recording tide gauge. In: Douglas BC, Kearney MS, Leatherman SP, editors. Sea level rise. San Diego: Academic Press. p. 37-64. doi:10.1016/s0074-6142(01)80006-1.

Eggleston J, Pope J. 2013. Land subsidence and relative sea-level rise in the southern Chesapeake Bay region. Circular 1392. Virginia: US Geological Survey. doi: 10.3133/CIR1392.

Fenoglio-Marc L, Schöne T, Illigner J, Becker M, Manurung P, Khafid. 2012. Sea level change and vertical motion from satellite altimetry, tide gauges and GPS in the Indonesian region. Mar Geod. 35(SUPPL. 1):137-150. doi: 10.1080/01490419.2012.718682.

Fu LLF, Cazenave A. 2001. Satellite altimetry and earth sciences: a handbook of techniques and applications. 1st edition. San Diego: Academic Press.

Gerhard LC, Harrison WE, Hanson BM. 2001. Geological perspectives of global climate change. Tusla: American Association of Petroleum Geologists. doi:10.1306/st47 737.

Hanh PTT, Furukawa M. 2007. Impact of sea level rise on coastal zone of Vietnam. Bull Fac Sci Univ Ryukyus. 84:45-59.

Hieronymus M. 2019. An update on the thermosteric sea level rise commitment to global warming. Environ Res Lett. 14(5):054018. doi:10.1088/1748-9326/ab1c31. 
Horton BP, Shennan I. 2009. Compaction of Holocene strata and the implications for relative sealevel change on the east coast of England. Geology. 37(12):1083-1086. doi: 10.1130/G30042A.1.

[ICCSR] Indonesia Climate Change Sectoral Roadmap. 2010. Scientific basis: analysis and projection of sea level rise and extreme weather events. Jakarta: Ministry of $\mathrm{Na}-$ tional Development Planning or National Development Planning Agency, Republic of Indonesia. https://www. bappenas.go.id/files/2013/5229/9917/analysis-and - projection-of-sea-level-rise-and-extreme-weathe _20110217130224__1.pdf.

Ingebritsen SE, Galloway DL. 2014. Coastal subsidence and relative sea level rise. Environ Res Lett. 9(9):091002. doi: 10.1088/1748-9326/9/9/091002.

[IPCC] Intergovernmental Panel on Climate Change. 2007. Climate change 2007: the physical science basis. In: Working group I: contribution to the fourth assessment report of the IPCC. Cambridge: Cambridge University Press.

Kolker AS, Allison MA, Hameed S. 2011. An evaluation of subsidence rates and sea-level variability in the northern Gulf of Mexico. Geophys Res Lett. 38(21):L21404. doi:10.1029/2011GL049458.

Kopp RE, Hay CC, Little CM, Mitrovica JX. 2015. Geographic variability of sea-level change. Curr Clim Change Rep. 1(3):192-204. doi:10.1007/s40641-015-0015-5.

Kopp RE, Kemp AC, Bittermann K, Horton BP, Donnelly JP, Gehrels WR, Hay CC, Mitrovica JX, Morrow ED, Rahmstorf S. 2016. Temperature-driven global sea-level variability in the Common Era. Proc Natl Acad Sci USA. 113(11):E1434-E1441. doi:10.1073/pnas.1517056113.

Levitus S, Antonov JI, Boyer TP, Baranova OK, Garcia HE, Locarnini RA, Mishonov AV, Reagan JR, Seidov D, Yarosh ES, Zweng MM. 2012. World ocean heat content and thermosteric sea level change (0-2000m), 1955-2010. Geophys Res Lett. 39(10). doi:10.1029/2012GL051106.

Luu QH, Tkalich P, Tay TW. 2015. Sea level trend and variability around Peninsular Malaysia. Ocean Sci. 11(4):617628. doi:10.5194/os-11-617-2015.

Mansawan AA, Gaol JL, Panjaitan JP. 2017. Variation and trend of sea level derived from altimetry satellite and tide gauge in Cilacap and Benoa coastal areas. Int J Remote Sens Earth Sci. 13(1):59-66. doi:10.30536/j.ijreses .2016.v13.a2703.

Nababan B, Hadianti S, Natih N. 2015. Dynamic of sea level anomaly of Indonesian waters (in Bahasa Indonesia). Jurnal Ilmu dan Teknologi Kelautan Tropis. 7(1):259-272. doi:10.29244/jitkt.v7i1.9943.

Nerem RS, Beckley BD, Fasullo JT, Hamlington BD, Masters D, Mitchum GT. 2018. Climate-change-driven accelerated sea-level rise detected in the altimeter era. Proc Natl Acad Sci USA. 115(9):2022-2025. doi:10.1073/pnas .1717312115 .

Nicholls R, Wong P, Burkett V, Codignotto JO, Hay J, Roger F M, Ragoonaden S, Woodroffe CD. 2007. Coastal systems and low-lying areas. In: Parry ML, Canziani OF, Palutikof JP, van der Linden PJ, Hanson C, editors. Climate Change 2007: impacts, adaptation and vulnerability. Contribution of Working Group II to the Fourth Assessment Report of the Intergovernmental Panel on Climate Change. Cambridge: Cambridge University Press. p. 315-356.
Nikolov T. 2012. A possible connection between some meteorological and climatic phenomena and earth's hot spots. Proc Bulg Acad Sci. 65(6):839-846.

[NOAA] National Oceanic and Atmospheric Administration. 2020. Laboratory for satellite altimetry/sea level rise. Silver Spring: National Oceanic and Atmospheric Administration; [accessed 2020 Jul 1]. https://www.star .nesdis.noaa.gov/socd/lsa/SeaLevelRise.

Paw JN, Thia-Eng C. 1991. Climate changes and sea level rise: implications on coastal area utilization and management in South-east Asia. Ocean Shoreline Manage. 15(3):205-232. doi:10.1016/0951-8312(91)90043-2.

Phien-wej N, Giao PH, Nutalaya P. 2006. Land subsidence in Bangkok, Thailand. Eng Geol. 82(4):187-201. doi:10.1 016/j.enggeo.2005.10.004.

Purba NP, Faizal I, Damanik FS, Rachim FR, Mulyani PG. 2020. Overview of oceanic eddies in Indonesia seas based on the sea surface temperature and sea surface height. World Sci News. 147:166-178.

Sarah D, Soebowo E. 2018. Land subsidence threats and its management in the North Coast of Java. IOP Conf Ser: Earth Environ Sci. 118(1):012042. doi:10.1088/1755-131 5/118/1/012042.

Sarwar GM, Khan MH. 2007. Sea level rise. A threat to the coast of Bangladesh. Int Asienforum. 38(3-4):375-397. doi:10.11588/iaf.2007.38.329.

Sofian I. 2013. Estimating the steric sea level rise in Indonesian seas using an oceanic general circulation model. Int J Geoinformatics. 9(3):1-7.

Sofian I, Kozai K, Ohsawa T. 2008. Investigation on the relationship between wind-induced volume transport and mean sea level in the Java Sea using an oceanic general circulation model. J Meteorol Soc Japan. 83(4):127-139. https://warp.da.ndl.go.jp/info:ndljp/pid/9493089/ www.umitosora.org/umisora_pdf/vol83_4_1.pdf.

Sofian I, Nahib I. 2010. Sea level rise projections by using altimeter data and IPCC-AR4 models (in Bahasa Indonesia). Globe. 12(2):173-181.

Sofian I, Supangat A, Fitriyanto MS, Kurniawan R. 2011. Understanding and anticipating the impact of climate change in coastal and seas in eastern Indonesia (in Bahasa Indonesia). J Meteorologi Geofisika. 12(1):53-64. doi:10.31172/jmg.v12i1.86.

Sojisuporn P, Sangmanee C, Wattayakorn G. 2013. Recent estimate of sea-level rise in the Gulf of Thailand. Maejo Int J Sci Technol. 7 (Special Issue):106-113.

Sprintall J. 2009. Indonesian throughflow. In: Steele JH, editor. Encyclopedia of ocean sciences. 2nd edition. Oxford: Academic Press. p. 237-243. doi:10.1016/B978-0 12374473-9.00602-0.

Stammer D, Cazenave A, Ponte RM, Tamisiea ME. 2013. Causes for contemporary regional sea level changes. Ann Rev Mar Sci. 5(1):21-46. doi:10.1146/annurev-mari ne-121211-172406.

Wibowo PLA, Hartoko A, Ambariyanto A. 2015. Land subsidence affects coastal zone vulnerability (Pengaruh penurunan tanah terhadap kerentanan wilayah pesisir). Ilmu Kelautan: Indonesian Journal of Marine Sciences. 20(3):127-134. doi:10.14710/ik.ijms.20.3.127-134.

Widodo A. 2017. Analyzing Indonesia's NCICD project to stop the capital city sinking. Otoritas: Jurnal Ilmu Pemerintahan. 7(2):54-66. doi:10.26618/ojip.v7i2.769. 